\title{
Ultrasound guidance for internal jugular vein cannulation: Continuing Professional Development
}

\author{
Christian Ayoub, MD • Catherine Lavallée, MD • \\ André Denault, MD, PhD
}

Received: 18 November 2009/Accepted: 15 February 2010/Published online: 7 April 2010

(C) Canadian Anesthesiologists' Society 2010

\begin{abstract}
Purpose The objective of this continuing professional development module is to describe the role of ultrasound for central venous catheterization and to specify its benefits and limitations. Although ultrasound techniques are useful for all central venous access sites, the focus of this module is on the internal jugular vein approach.

Principal findings In recent years, several studies were published on the benefits of ultrasound use for central venous catheterization. This technique has evolved rapidly due to improvements in the equipment and technology available. Ultrasound helps to detect the anatomical variants of the internal jugular vein. The typical anterolateral position of the internal jugular vein with respect to the carotid is found in only 9-92\% of cases. Ultrasound guidance reduces the rate of mechanical, infectious, and thrombotic complications by 57\%, and it also reduces the failure rate by $86 \%$. Cost-benefit analyses show that the cost of ultrasound equipment is compensated by the decrease in the expenses associated with the treatment of complications. In this article, we will review the history of
\end{abstract}

Electronic supplementary material The online version of this article (doi:10.1007/s12630-010-9291-7) contains supplementary material, which is available to authorized users.

C. Ayoub, MD $(\bowtie) \cdot$ C. Lavallée, MD · A. Denault, MD, PhD Département d'anesthésiologie, Département d'anesthésiologie et centre de recherche, Institut de Cardiologie de Montréal, Université de Montréal, 5000 Rue Bélanger, Montreal, QC H1T 1C8, Canada

e-mail: cr.ayoub@umontreal.ca; ayoub_christian@hotmail.com ultrasound guidance as well as the reasons that account for its superiority over the classical anatomical landmark technique. We will describe the equipment needed for central venous catheterization as well as the various methods to visualize with ultrasound.

Conclusion To improve patient safety, we recommend the use of ultrasound for central venous catheterization using the internal jugular approach.

\section{Objectives}

After reading this module, the reader will be able to:

1. Understand the rationale behind the use of ultrasound for central venous catheterization;

2. Identify anatomical variations in vascular structures in the neck;

3. Recognize the benefits and limitations related to the use of ultrasound; and

4. Adopt an ultrasound-guided approach in everyday practice.

Over the years, anesthesiologists have adopted new technologies that are used for clinical monitoring and intraoperative diagnosis as well as for performing various techniques. These advances assist the anesthesiologist in performing procedures that may be associated with significant complications. One such procedure is central venous catheterization, which can be simplified and made safer with ultrasound. The main objective of this article is to explain the scientific and clinical foundations supporting the role of ultrasound in central venous catheterization. We will focus exclusively on the internal jugular vein approach. 


\section{Historical perspective}

The main indications for central venous catheterization in the operating room or intensive care unit (ICU) include central venous pressure monitoring, the insertion of a pulmonary artery catheter, and the administration of drugs, such as antibiotics, vasopressors, inotropes, and chemotherapeutic agents. These catheters are also used to administer parenteral nutritional support, and they are needed for procedures such as hemodialysis, hemofiltration, and plasmapheresis. Commonly used in electrophysiology and cardiac catheterization laboratories, they facilitate the placement of temporary or permanent pacemakers.

At first, the only available option for central venous catheterization was the technique involving percutaneous puncture based on various anatomical landmarks. Without access to ultrasound, the success of this technique was highly dependent on the clinical experience of the physician and his/her knowledge of anatomy. ${ }^{1}$ The most popular sites for this technique have remained the same over time, i.e., the internal jugular vein, the subclavian vein, and the femoral vein. As for the selection of the puncture site, often the decision is based on convenience, ease of access, and patient comfort.

\section{Internal jugular vein catheterization}

In 1969, English et al. were the first to describe internal jugular vein catheterization. ${ }^{2}$ This technique soon became popular due to its advantages compared with other approaches. The location of the internal jugular vein in relation to neighbouring vascular and muscular structures is predictable. Additionally, the right internal jugular vein is preferred to the left because of its larger diameter, its distance from the thoracic duct (located on the left), ${ }^{3}$ and the fact that it forms a straight axis with the superior vena cava and the right atrium.

Despite the acceptable success rate obtained with this landmark technique, the complication rate varies from $2-19 \%$ in the literature, and it may be as high as $40 \%$ if catheterization failure is included. ${ }^{1,4,5}$ Generally, complications are divided into three major categories for analytical purposes, i.e., mechanical, infectious, and thrombotic. Mechanical complications include inadvertent arterial puncture, hematoma, pneumothorax or pneumomediastinum, and neurological injury to the brachial plexus, inferior cervical ganglion, and phrenic or recurrent laryngeal nerves. The incidence of these complications varies from $6.3-11.8 \% .^{5,6}$ Infectious complications occur in $5-26 \%$ of cases, and their seriousness ranges from a site infection to generalized septicemia. $^{5,6}$ Finally, thrombotic complications occur in approximately $15 \%$ of cases and develop particularly with multiple punctures seen in hemodialysis patients. ${ }^{5,6}$
Ultrasound techniques

As early as 1978, ultrasound-guided central catheterization was described as an effective technique to reduce the rate of mechanical complications. ${ }^{7}$ Ullman et al. were among the first to describe the use of a Doppler probe for central catheterization. ${ }^{8}$ Then, in 1984, Legler and Nugent published the first guidelines on the use of Doppler ultrasound. ${ }^{9}$ Since the beginning of the $21^{\text {st }}$ century, several health agencies, such as the British National Institute for Clinical Excellence and the Agency for Healthcare Research and Quality Evidence, have published guidelines supporting the use of ultrasound. These recommendations were based on studies that show a significant decrease in the rate of failed punctures $(86 \%)$, a reduction in complications $(57 \%)$, and a shorter performance time (1.1 min vs $2.6 \mathrm{~min}) .^{10,11}$ An opposite view was voiced by Grebenik et al., ${ }^{12}$ who questioned these guidelines regarding pediatric catheterization. However, most studies tend to support the opinion of these agencies. Over the past few years, ultrasound has undergone rapid development following the miniaturization of devices, the reduction of its cost, and aggressive marketing by the manufacturers. This evolution also took place with respect to the performance of peripheral nerve blocks in regional anesthesia and other ultrasound applications in the ICU.

\section{Anatomical variants}

Generally, we expect to find the internal jugular vein anterior and lateral to the carotid artery. However, this theoretical position is confirmed by ultrasound in only 9-92\% of cases. ${ }^{1}$ In over half of the patients, approximately $50 \%$ of the vein's surface is located in front of the artery. Consequently, it is quite possible to puncture the artery by going through the posterior wall of the internal jugular vein. The degree of overlap of the vein and artery depends on the location of the puncture site in the neck. In addition, in $1-5 \%$ of patients, the jugular vein is medial to the carotid, and in $3-18 \%$ of patients, the internal jugular vein is thrombosed or absent. ${ }^{1,13}$ The mean diameter of the right internal jugular is $11.5 \mathrm{~mm}$, but it can be less than $5 \mathrm{~mm}$ in $13-18 \%$ of cases. ${ }^{14,15}$ Thus, it is not surprising to find only partial success when puncturing laterally to the artery using the blind technique (Figure 1, Table 1)

Anatomical variations can be observed between the left and right jugular vein in the same individual. According to Modeliar et al., the diameter of the jugular vein is significantly larger on the right than on the left in $65 \%$ of cases. ${ }^{15}$ In another study, Lichtenstein et al. evaluated the asymmetry between the right and left jugular veins. Asymmetry was defined as an area twice as large as the 
Fig. 1 Anatomical variants of the right jugular vein with respect to the carotid artery. The right internal jugular vein (RIJV) is expected to be anterolateral to the carotid. This diagram describes the various positions of the jugular with respect to the artery. In over half of the patients, approximately $50 \%$ of the jugular vein surface area is anterior to the carotid. ${ }^{1}$

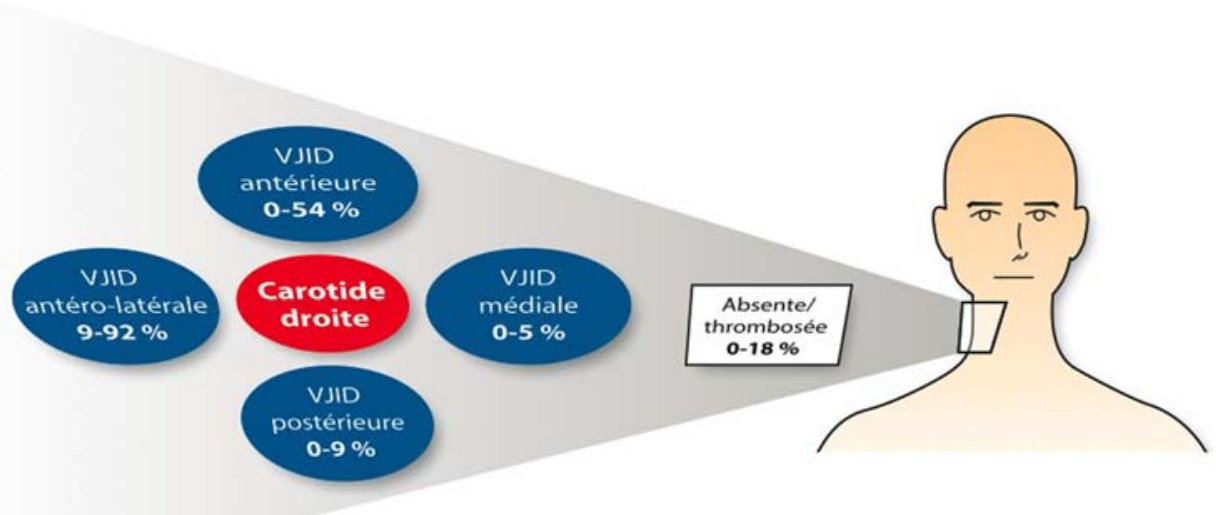

Table 1 Benefits and drawbacks of ultrasound use for central venous catheterization

$\mathrm{IJV}=$ Internal jugular vein

\begin{tabular}{|c|c|}
\hline Benefits & Drawbacks \\
\hline 1. Visualization of vascular structures & 1. Technological dependency \\
\hline 2. Optimal needle placement & $\begin{array}{l}\text { 2. Loss of technical abilities when using anatomical } \\
\text { landmarks }\end{array}$ \\
\hline $\begin{array}{l}\text { 3. Protection against puncture of the posterior } \\
\text { wall of the IJV }\end{array}$ & 3. Lack of awareness of one's environment \\
\hline 4. Accurate placement of catheter inside the IJV & 4. False sense of security \\
\hline 5. Confirmation of the guidewire inside the IJV & 5. Increased equipment costs \\
\hline \multicolumn{2}{|l|}{ 6. Shorter performance time } \\
\hline \multicolumn{2}{|l|}{ 7. Lower number of attempts } \\
\hline 8. Lower complication rate & \\
\hline
\end{tabular}

opposite side and was noted in $62 \%$ of cases, the right jugular vein being dominant in $68 \%$ of patients. ${ }^{13}$

In some patients, surface landmarks can be difficult or even impossible to locate due to modified surface anatomy, radiotherapy, obesity, edema, burns, or prior surgery. Success with insertion of central venous catheters also depends on the size of the internal jugular vein, the patient's blood volume, positioning, head rotation, pressure on the skin, and presence of trauma. For all of these reasons and despite the operator's possible extensive experience, it is sometimes impossible to puncture the vein.

Positive pressure ventilation as well as a $30^{\circ}$ head rotation to the side opposite the puncture site further causes the neck vessels to overlap. ${ }^{16,17}$ Finally, the use of a laryngeal mask airway can displace the sternocleidomastoid muscle and further complicate palpation of the common carotid artery.

\section{Ultrasound-guided catheterization techniques}

The static approach

There are two possible approaches when using ultrasound. The first approach involves a preliminary visualization of the anatomical structures exclusively for anatomical identification. Although the benefit of this so-called "static" method is limited, it is superior to the landmark technique allowing visualization of the internal jugular vein and any contraindications to its cannulation. Next, the location of the internal jugular vein is drawn on the skin with a sterile pencil. The rest of this technique is performed in a "blind" manner based on the visual landmarks previously identified.

The dynamic approach

We recommend the second so-called "dynamic" approach, which is also called the "real-time" ultrasound location. It includes anatomical identification but also involves following the progression of the needle and confirming the position of the guidewire within the internal jugular vein.

\section{Choice of probe and methods}

Frequency

Two types of ultrasound probes are currently available on the market, i.e., high-frequency (8-12 MHz) and 
Fig. 2 Images of the right internal jugular vein (RIJV) and the right carotid artery (RCA) in a transverse (A-C) and longitudinal (D-F) plane. The choice of probe frequency is based on the resolution and penetration desired. Images obtained with a $10 \mathrm{MHz}$ probe (A, D) are more detailed. However, the RCA, usually deeper, is better seen with a $2 \mathrm{MHz}$ probe (with the permission of Denault et al.). ${ }^{18}$
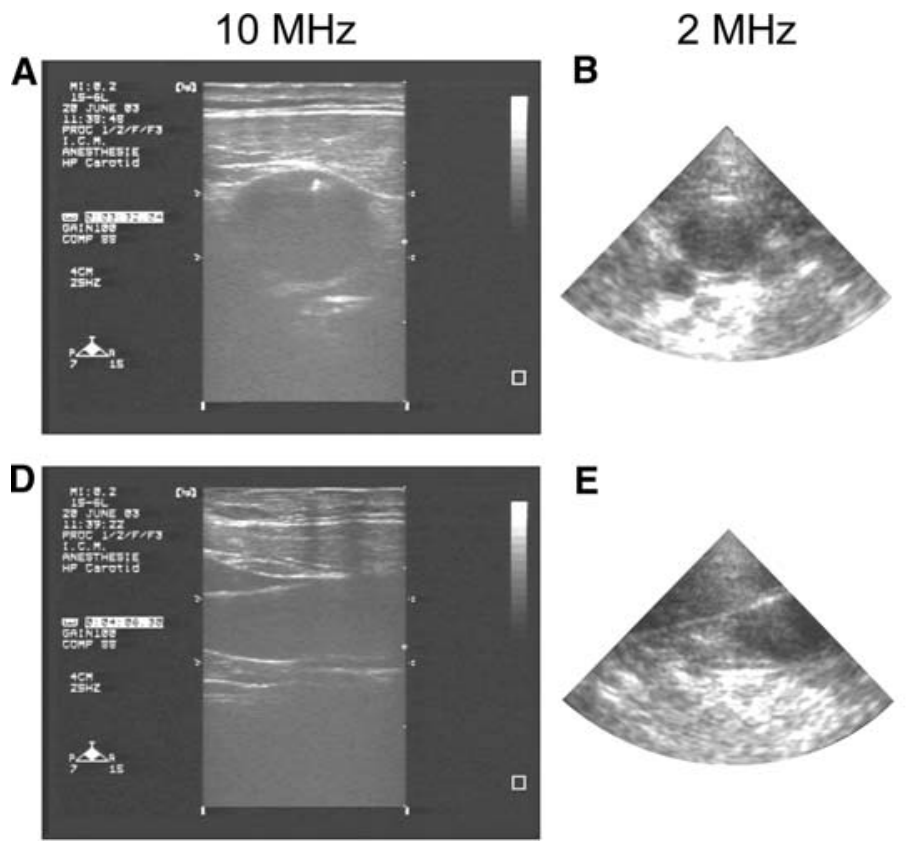

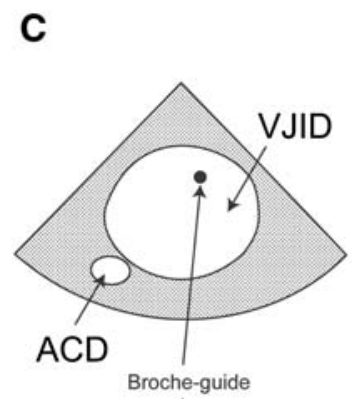

E
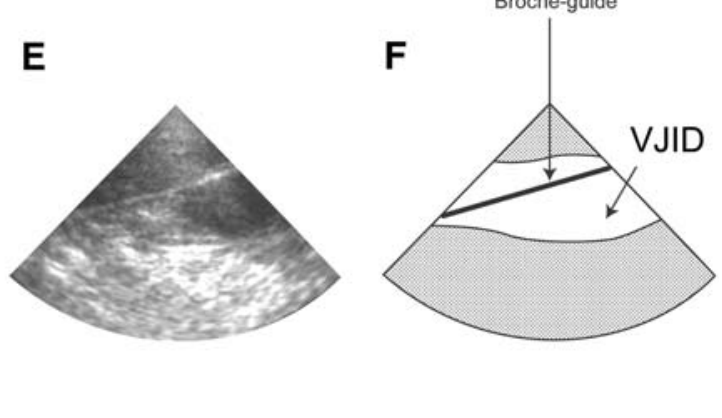

low-frequency probes (1-4 MHz). The choice of probe depends on the quality of image one wishes to obtain as well as the depth of the targeted structure. Resolution refers to the ability to distinguish two adjacent anatomical structures. The higher the frequency of the probe, the shorter the wavelength and the better the resolution. On the other hand, high frequencies provide image clarity for only a limited depth (Figure 2). ${ }^{19}$ In general, high-frequency probes are used, as the internal jugular vein is relatively superficial.

\section{Doppler and 2D modes}

Before the development of two-dimensional (2D) ultrasound, the Doppler mode was the only available technique. It enables the identification of vascular structures by analyzing the sound signal produced by the blood flow. In contrast to the high-frequency pulsatile arterial signal, a venous signal is characterized by a low frequency that varies with the respiratory cycle. Nowadays, 2D ultrasound is used in order to generate the image produced by subcutaneous structures. Colour Doppler can be added to this 2D mode in order to estimate the velocity of blood and its direction. This mode is useful in cases presenting a true distortion of anatomical and vascular structures.

\section{Cannulation technique}

The equipment needed to perform ultrasound catheterization includes an ultrasound device, an appropriate probe selected according to the depth of the target being punctured, and a sterile sheath to isolate the probe from the patient. The presence of an assistant is also useful. The patient is placed in a supine position, with or without the Trendelenburg position, and with a slight head rotation toward the opposite direction. The rotation angle should never be greater than $30^{\circ}$ because of the anatomical distortion this might cause. This exaggerated cervical rotation can cause a greater overlap of the internal jugular vein with the carotid artery and therefore increase the likelihood of arterial puncture. $^{20}$

The patient's skin is disinfected at all possible catheterization sites, including both jugular and both subclavian vein sites (Figure 7 available as Electronic Supplementary Material). The ultrasound probe is then placed in a sterile sheath coated with sterile ultrasound gel. The gel serves as an interface and increases the transmission of ultrasound waves (Figures 8-10 available as Electronic Supplementary Material). The use of a saline solution on the skin is preferred over gel for sheath-skin interface. If the sheath is perforated, gel will escape on the patient's skin making the area no longer sterile. Identification of the vein is made with the probe placed perpendicular to the skin in order to get a transverse view of the vessels (Figures 3 and 4). At this point, the gain, frequency, and depth are adjusted.

\section{Identifying the vein}

The vein has two distinctive features, i.e., it can be compressed and its calibre varies with the respiratory cycle. Hepatojugular reflux, which can be generated by applying 


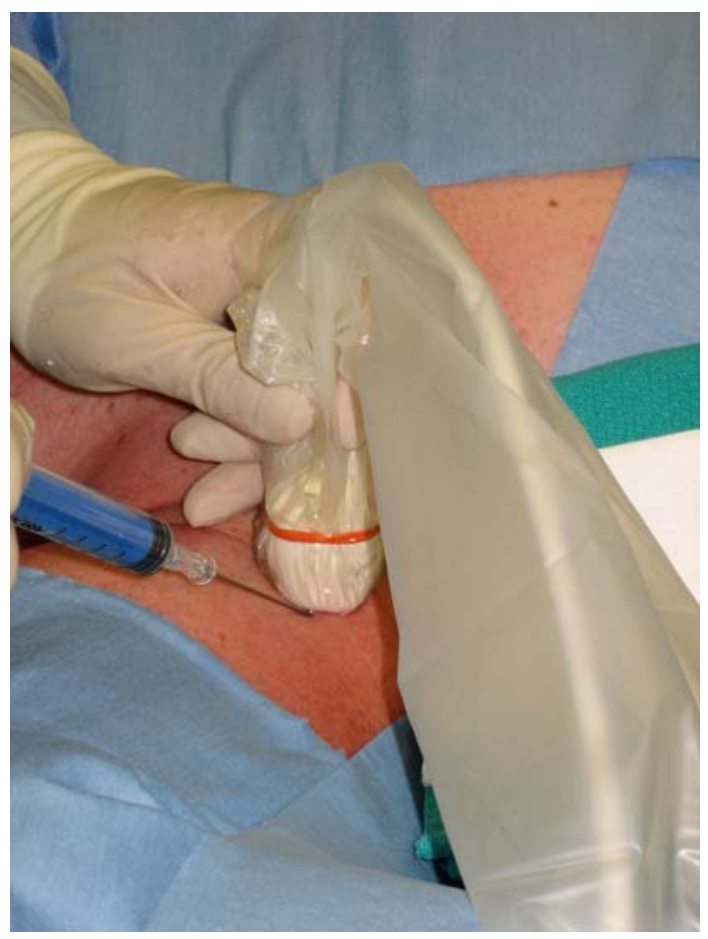

Fig. 3 Puncture of the right internal jugular vein seen from the patient's head. The probe is placed in a short axis view with the needle cephalad to it

pressure on the liver, might increase the size of the jugular vein. The Trendelenburg position also increases the surface area of the jugular vein by $37 \%$ on average, and the maximum diameter can be reached at a $15^{\circ}$ angle. ${ }^{19}$ If the trachea is not intubated, the Valsalva maneuver will tend to increase the cross-sectional area of the internal jugular vein by $25 \% .{ }^{19}$ At this point, it is important to recognize thrombosis or atrophy of the internal jugular vein, both of which are absolute contraindications to jugular vein catheterization

\section{View axis}

When learning the technique, it is easier to use a "short axis" view, perpendicular to the vein, to identify the position of the internal jugular vein with respect to the carotid artery. With this view, both the vein and the artery, which appear round or oval, are recognized easily (Figure 4). While one hand pushes the needle forward, the other hand must either slide the probe or angle it to maintain the tip of the needle in the image plane. With more experience, the operator may prefer the "long axis" approach parallel to the vein, which allows a better visualization of the entire path of the needle and the introduction of the guidewire. This approach decreases the probability of posterior wall puncture (Figurs 5 and 6). Usually, the carotid artery is not visualized with the long

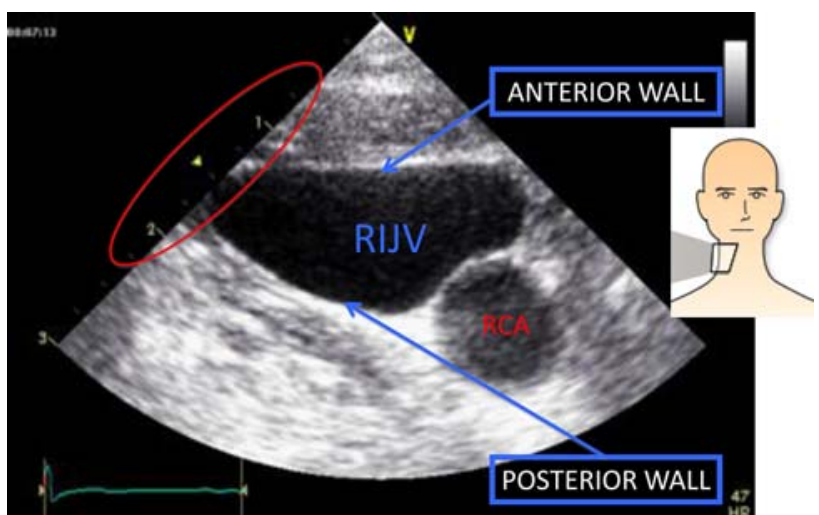

Fig. 4 Structures on the right side of the neck. The internal jugular vein can be shallow and is usually less than $2 \mathrm{~cm}$ under the skin

axis view. In order to succeed with this technique, the operator should start with a "short axis" approach and should make certain the needle is exactly over the vein. Once this position has been reached, the probe should be turned $90^{\circ}$ to obtain a "long axis" view. The probe is then positioned over the tip of the needle. The angle between the needle and the skin should then be reduced to approximately $30^{\circ}$. Once the needle tip is visualized with the ultrasound probe, only the hand controlling the needle should move in order to stay in view. This longitudinal technique is the one used and recommended by radiology experts. No matter which technique is chosen, it is crucial never to push the needle forward without visualizing it. This mistake, often made by beginners, is the reason why the ultrasound location technique can also be associated with complications. The technique is summarized in videos 1 and 2.

\section{Depth}

Figures 5 and 6 show that the vein is relatively superficial to the cutaneous plane and located at a depth of approximately $1.5-2 \mathrm{~cm}$. Therefore, it is useless and even risky to push the needle further than $2.5-3 \mathrm{~cm}$. In addition, by pushing the needle too deep, there is a risk of puncturing the posterior wall of the vein, causing a hematoma. This pitfall can be avoided with the longitudinal technique.

During an ultrasound-guided puncture, it is important to carefully follow the path of the needle tip rather than the tissue movement it causes. Additionally, before puncturing the skin, it is crucial to visualize the skin plane where the puncture is planned in order to identify the structures. This step will avoid punctures that are too lateral towards the sternocleidomastoid muscle or too inferomedial in the direction of the thyroid gland or the carotid artery. Once the vein is identified and punctured, the probe can be set 


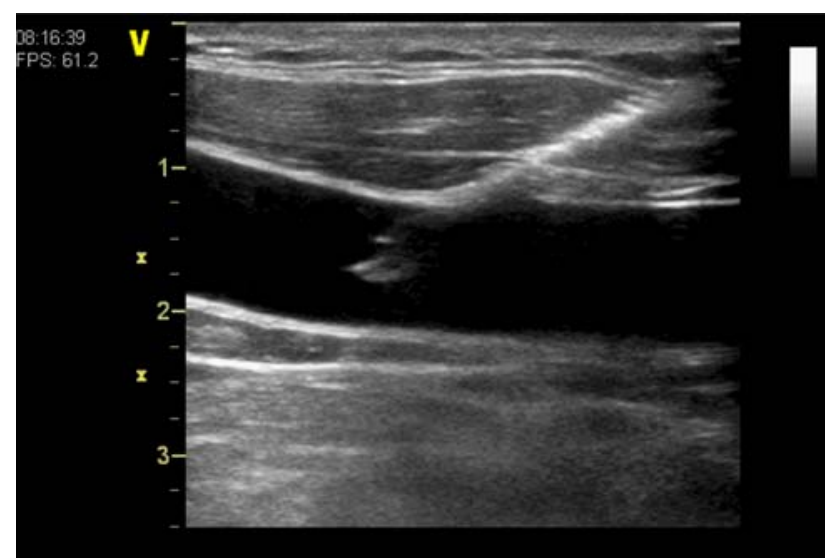

Fig. 5 Image of the needle tip in a long axis view

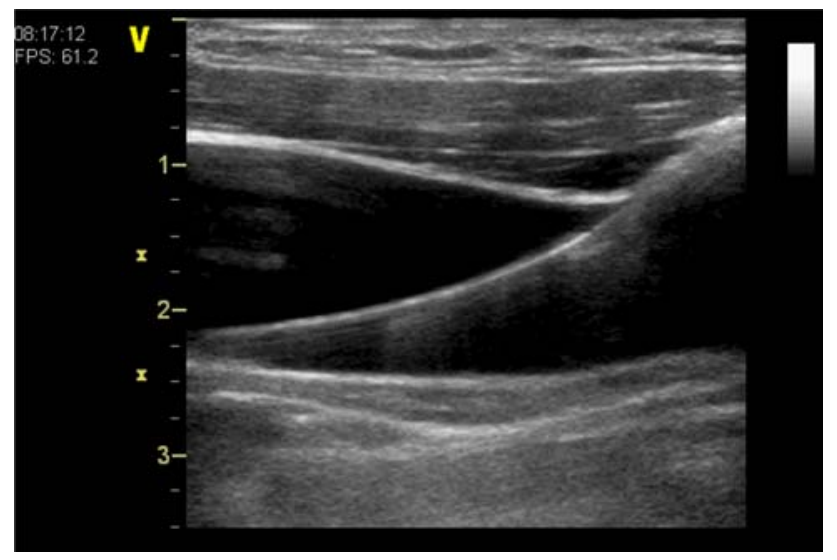

Fig. 6 Image of the guidewire in the right internal jugular vein in a long axis view

aside and the guidewire inserted. The needle is then removed, and the guidewire position in the internal jugular vein is confirmed with the ultrasound probe. Also, the operator could adjust the visualization axis in order to see the insertion of the guidewire in real time using a long axis view. If a transesophageal ultrasound probe is in place, observing the guidewire in the right atrium will confirm adequate venous cannulation.

\section{Technique assessment}

Benefits

Several studies show clear benefits associated with the use of ultrasound. ${ }^{1,5,7}$ The benefits include a reduced rate of complications and failure, a reduced number of attempts, and a faster performance time. ${ }^{21-24}$ These results are due to visualization of the needle and its position relative to the structures. In addition, 2D ultrasound helps to predict anatomical variations and confirms the patency of the internal jugular vein. Karakitsos et al. undertook an important study comparing ultrasound guidance with the landmark technique in 900 ICU patients. ${ }^{25}$ The operators had ten years' experience in inserting vascular catheters without ultrasound and five years' experience with ultrasound guidance. The success rate was $100 \%$ with ultrasound and $94 \%$ when relying on the traditional landmarks alone. There was a faster mean access time and a lower mean number of attempts with ultrasound compared with the landmark technique (17 sec vs $44 \mathrm{sec}$, respectively and 1.1 attempts $v s 2.6$ attempts, respectively). With ultrasound, the complication rate was reduced by $57 \%$. The authors observed a significant difference in favour of ultrasound in the incidence of punctures of the carotid artery $(1.1 \%$ vs $10.6 \%)$, hematoma $(0.4 \%$ vs $8.4 \%)$, pneumothorax (0\% vs 2.4\%), hemothorax ( $0 \%$ vs $1.7 \%)$, and infections $(10.4 \%$ vs $16 \%) .{ }^{25}$ Also, according to Hind et al. and Calvert et al., there were $86 \%$ fewer failures and $41 \%$ fewer failures on the first attempt. ${ }^{7,26}$ These studies were used to establish the 2003 National Institute for Clinical Excellence recommendations. In a study evaluating lawsuits, Domino et al. concluded that the use of ultrasound could have prevented incidents in 28 patients out of 110 patients involved in a legal action. ${ }^{27}$

\section{Pneumothorax}

In most cases, central venous catheterization is performed at the beginning of a surgical procedure, but a chest radiograph is often obtained only at the end of surgery. The "sliding lung" technique consists of a rapid ultrasound assessment of the lung and pleura. It has been proven effective in detecting the presence of a pneumothorax. Indeed, its negative predictive value approaches $100 \%$ in some studies. ${ }^{28-30}$ Thus, if the "sliding lung" sign is absent, the pneumothorax can be confirmed, which prevents the delay in diagnosis. In addition, this recent yet clinically effective technique has been shown to be more effective than chest radiography in detecting small size pneumothoraces (video 3). ${ }^{31}$

\section{Drawbacks}

As with any new technique, using ultrasound requires training on its basic principles. These concepts can be acquired relatively quickly, as evidenced by a rapid learning curve. However, the systematic use of ultrasound can induce a technological dependency, which may cause worry about losing one's technical abilities due to lack of practice. Thus, when the device is unavailable or in an emergency situation, 
the clinician may feel uncomfortable or unable to proceed. In fact, this technical dependency can be compared with the use of a laryngoscope for intubation. This tool is essential to our practice and is readily available in any urgent and elective situation. Ultrasound may follow the same evolution and become part of the basic anesthetic equipment. In addition, there is a real acquisition cost that needs to be taken into account. Also, 2D ultrasound can give a false sense of security, causing the operator to forget basic safety steps and precautions. When concentrating on the ultrasound image, the operator may forget to look at the patient and the surroundings. The Table summarizes the benefits and drawbacks of ultrasound use for central venous catheterization.

\section{Costs}

A comparative cost-benefit analysis must take into account the treatment of complications associated with central venous catheterization and the prolonged hospital stay these may require. Consequently, the costs related to not using ultrasound are significant. Economic models created in the UK by the Health Technology Assessment Programme have shown that ultrasound use could result in savings of almost $\$ 4,000$ per 1,000 procedures. The calculations took into account the costs related to arterial punctures, pneumothoraces, and equipment acquisition. ${ }^{26}$ In another study assessing ultrasound use for subclavian punctures, the investigators considered the number of kits used. Compared with ultrasound users, who used only one kit, users relying exclusively on skin landmarks often used more than one kit to perform their puncture. ${ }^{31}$ For these reasons, despite the higher cost of ultrasound acquisition, these expenses can be mitigated by the reduced number of related complications.

\section{Current perceptions among anesthesiologists}

Despite the supporting evidence for ultrasound, clinicians are often reluctant to use this technique for central venous catheterization. According to a survey conducted among the members of the American Society of Cardiovascular Anesthesiologists, two-thirds of respondents stated that they had never or had rarely used ultrasound. In addition, only $15 \%$ of members used it systematically. In about $45 \%$ of cases, the anesthesiologists mentioned not feeling any need to use itdespite the fact that more than $75 \%$ of them have witnessed complications. The cost, the lack of equipment, and the delays caused are among the other reasons mentioned by clinicians to justify the under-use of this technology. Surprisingly, we noted that more than $45 \%$ of anesthesiologists still use colour and non-pulsatility of blood return to confirm the position of the needle while being aware that these techniques are not failsafe. ${ }^{4}$ Considering this data, it is obvious that a great deal of effort is needed to promote the use of ultrasound for central venous catheterization by physicians.

\section{Conclusion}

Ultrasound use for insertion of central venous catheters reduces mechanical and infectious complications and increases the success rate and effectiveness while possibly reducing costs and patient discomfort. Provided that the equipment is available and the training is appropriate, the use of ultrasound is recommended in all patients requiring a central venous access. This technique should be adopted by new clinicians and experienced practitioners as their first line treatment, especially in cases of obesity, edema, coagulation disorders, difficult anatomical landmarks, or positive pressure ventilation in the ICU. Due to the proven benefits of this technique, which ultimately contribute to better patient safety, it will become difficult to justify not using ultrasound when inserting central venous catheters.

\section{Case scenario}

A 66-yr-old obese man presents to the emergency department in cardiogenic shock with acute pulmonary edema. $\mathrm{He}$ is treated for arterial hypertension and dyslipidemia. His medical history includes type 2 insulin-dependent diabetes mellitus, coronary artery disease, and hemodialysis-dependent end-stage renal failure. The patient is in a semi-seated position; he is dyspneic and is using his accessory muscles. In addition, his blood pressure is 85 / $40 \mathrm{mmHg}$. Your colleague wishes to insert a central line to give the patient vasopressors and asks for your help because he believes the procedure will be difficult.

\section{Instructions for completing the continuing professional development (CPD) module}

(1) Read the current article and the references indicated in bold.

(2) Go to: https://www.cpass2.umontreal.ca/selfassessment program/ and select the current module (Ultrasound guidance for internal jugular vein cannulation: Continuing Professional Development).

(3) Answer the multiple choice questions regarding the case scenario.

(4) When you have entered all of your answers, you will have access to experts' explanations for all the possible choices.

(5) Participants may claim up to $4 \mathrm{~h}$ of CPD, for a total of eight credits under Section 3 of the CPD program of the Royal College of Physicians and Surgeons of Canada. 


\section{L'échographie dans la canulation de la veine jugulaire interne}

\author{
Résumé \\ Objectif Ce module de développement professionnel \\ continu vise à décrire le rôle de l'échographie dans \\ l'installation de cathéters veineux centraux, en précisant ses \\ avantages et ses limites. Bien que l'échographie soit utile pour \\ la canulation de tous les sites d'accès veineux centraux, le \\ présent module priorisera l'abord de la veine jugulaire \\ interne.
}

Constatations principales $A u$ cours des dernières années, de nombreuses études ont été publiées démontrant et analysant les avantages de l'utilisation de l'échographie lors de l'installation de cathéters veineux centraux. Cette technique en plein essor a beaucoup évolué autant sur le plan du matériel disponible que du point de vue technique. Elle permet la détection des variations anatomiques de la veine jugulaire interne. En effet, la position classique antérolatérale de la veine jugulaire interne, par rapport à la carotide, ne se retrouve que dans 9-92 \% des cas. La technique échoguidée diminue le taux de complications mécaniques, infectieuses ou thrombotiques de $57 \%$. Elle diminue aussi le taux d'échecs de $86 \%$. Les analyses économiques indiquent que le coût $d u$ matériel d'échographie est largement compensé par la réduction des couts associés au traitement des complications. Nous abordons dans cet article l'historique et les raisons qui expliquent la supériorité de la technique échoguidée comparativement à la technique classique dite «à l'aveugle». Nous présentons le matériel nécessaire à la procédure, ainsi que les diverses techniques de visualisation par échographie.

Conclusions Pour améliorer la sécurité des patients, il est recommandé d'utiliser le repérage échographique pour toute installation de cathéters veineux centraux par abord jugulaire interne.

\section{Objectifs}

À la fin du présent module, le lecteur sera capable de :

1- Comprendre les raisons qui sous-tendent l'utilisation de l'échographie dans l'insertion des cathéters veineux centraux.

2- Identifier les variations anatomiques des structures vasculaires au niveau du cou.

3- Reconnaître les avantages et les limites liées à l'utilisation de l'échographie.

4- Adopter l'approche échoguidée afin de pouvoir l'utiliser dans sa pratique quotidienne.
L'anesthésiologiste a adopté au fil des années de nouvelles technologies qu'il applique au niveau du monitorage clinique, du diagnostic peropératoire et dans la réalisation de gestes techniques. Ces avancées permettent entre autres la réalisation de procédures en apparence simples mais associées à des complications non négligeables. C'est dans cet esprit que l'échographie a trouvé sa place dans l'installation des cathéters veineux centraux. La compréhension des bases scientifiques et cliniques qui appuient l'utilisation de l'échographie dans l'installation des cathéters veineux centraux est l'objectif principal de cet article. Nous nous limiterons à l'abord de la veine jugulaire interne.

\section{Perspective historique}

Les cathéters veineux centraux sont installés au bloc opératoire ou à l'unité de soins intensifs pour des indications très variées comme le monitorage de la tension veineuse centrale, la mise en place d'un cathéter de l'artère pulmonaire ou l'administration de médicaments tels que les antibiotiques, les vasopresseurs, les inotropes et les agents de chimiothérapie. Ces cathéters servent aussi à l'administration de support nutritionnel parentéral, et deviennent essentiels dans la réalisation de diverses interventions telles que l'hémodialyse, l'hémofiltration et la plasmaphérèse. Omniprésents dans les laboratoires d'électrophysiologie ou d'hémodynamie, ils permettent la pose de pacemakers temporaires ou permanents.

Au début, la technique de ponction percutanée utilisant différents repères anatomiques était la seule option disponible. Faute d'accès à l'échographie, le succès de cette technique dépendait alors de l'expérience clinique du médecin et de sa connaissance de l'anatomie. ${ }^{1}$ Les voies d'accès les plus couramment utilisées sont demeurées les mêmes à travers les décennies : les veines jugulaire interne, sous-clavière et fémorale. Quant au choix du site de ponction, il repose sur des considérations de commodité, de facilité d'accès et de confort pour le patient.

Canulation de la veine jugulaire interne

English et coll. ont été les premiers à décrire la canulation de la veine jugulaire interne en $1969 .^{2}$ Cette technique gagne rapidement en popularité en raison de ses avantages par rapport aux autres abords. En effet, la veine jugulaire interne offre, au niveau du cou, une relation prévisible par rapport aux structures vasculaires et musculaires voisines. D'autre part, la jugulaire interne droite est préférée à la gauche en raison de sa plus grande dimension, de son éloignement par rapport au canal thoracique (situé du côté 
gauche $^{3}$ ) et de l'axe direct qu'elle présente vers la veine cave supérieure et l'oreillette droite.

Malgré un taux de succès fort acceptable avec la technique à l'aveugle, le taux de complications varie de 2-19\% selon les sources retrouvées dans la littérature, et s'élève jusqu'à $40 \%$ si l'on inclut l'échec de la pose du cathéter. ${ }^{1,45}$ À des fins d'analyse, on divise généralement les complications en trois grandes catégories : les complications mécaniques, les complications infectieuses et les complications thrombotiques. On reconnaît comme complications mécaniques la ponction artérielle accidentelle, la formation d'hématome in situ, thoracique ou médiastinal, l'atteinte neurologique du plexus brachial, du ganglion stellaire, des nerfs phrénique ou récurrent laryngé, ainsi que la survenue d'un pneumothorax ou d'un pneumomédiastin. Ces complications mécaniques surviennent dans 6,3-11,8\% des cas. ${ }^{5,6}$ En ce qui a trait aux complications infectieuses, leur incidence oscille entre 5-26\% des cas et leur gravité va de la simple infection au site d'insertion du cathéter à la septicémie généralisée. ${ }^{5,6}$ Finalement, les complications thrombotiques surviennent dans environ $15 \%$ des cas et se rencontrent particulièrement chez les patients ayant eu de multiples ponctions comme par exemple les hémodialysés. ${ }^{5,6}$

\section{Techniques échographiques}

Dès 1978, l'insertion de cathéters centraux sous repérage échographique apparaît comme une intervention efficace pour diminuer le taux de complications mécaniques. ${ }^{7}$ En effet, Ullman et coll. font partie des pionniers à décrire l'emploi d'une sonde Doppler dans la pose des cathéters centraux. ${ }^{8}$ S'ensuivent en 1984, avec Legler et Nugent, les premières recommandations sur l'utilisation de l'écho Doppler. ${ }^{9}$ Dès le début des années 2000, plusieurs agences de santé telles que le National Institute for Clinical Excellence en Angleterre et l'Agency for HealthcareResearch and Quality Evidence émettent des recommandations qui appuient l'emploi de l'échographie. Ces recommandations sont basées sur des études qui démontrent de façon fortement significative une baisse du taux d'échec de ponction ( $86 \%$ ), une diminution des complications ( $57 \%$ ) ainsi qu'un temps d'exécution moindre $(1,1 \mathrm{~min}$ vs $2,6 \mathrm{~min}) .{ }^{10,11}$ Contrairement à Grebenik et coll., ${ }^{12}$ qui ont mis en doute ces lignes directrices lors de la pose de cathéters chez l'enfant, la plupart des études ont tendance à pencher en faveur de la position soutenue par ces organismes. L'échographie a connu un essor ces dernières années en raison de la miniaturisation des appareils, de la baisse des coûts et d'une commercialisation agressive des compagnies. Cette évolution s'est de plus réalisée en conjonction avec le développement des techniques échoguidées pour les blocs nerveux périphériques et dans diverses applications aux soins intensifs.

\section{Variations anatomiques}

On s'attend à trouver la veine jugulaire interne antérieurement et latéralement à l'artère carotide. Or cette position théorique n'est confirmée échographiquement que dans 9-92\% des cas. ${ }^{1}$ Chez plus de la moitié des patients, environ $50 \%$ de la surface de la veine est située devant l'artère. Il est donc possible de ponctionner l'artère en traversant la paroi postérieure de la veine jugulaire interne. Ce degré de superposition veno-artérielle varie selon le niveau de la ponction dans le cou. De plus, dans 1-5\% des cas, la veine jugulaire est située médiale à la carotide et dans 3-18\% des patients la veine jugulaire interne s'avère thrombosée ou absente. ${ }^{1,13}$ Le diamètre moyen de la jugulaire interne droite est de $11,5 \mathrm{~mm}$ mais peut être inférieur à $5 \mathrm{~mm}$ dans $13-18 \%$ des cas. ${ }^{14,15}$ Ainsi, en ponctionnant latéralement l'artère à l'aveugle, une réussite partielle n'est pas surprenante (Figure 1, Tableau 1).

Il existe aussi des variations anatomiques chez un même individu entre la veine jugulaire gauche et la droite. Selon

Fig. 1 Variations anatomiques de la veine jugulaire droite par rapport à la carotide. La veine jugulaire interne droite (VJID) se retrouve habituellement en antérolatéral par rapport à la carotide. Ce schéma décrit les diverses positions de la jugulaire par rapport à l'artère. Plus de la moitié des jugulaires ont $50 \%$ ou plus de leur aire antérieurement à la carotide. ${ }^{1}$

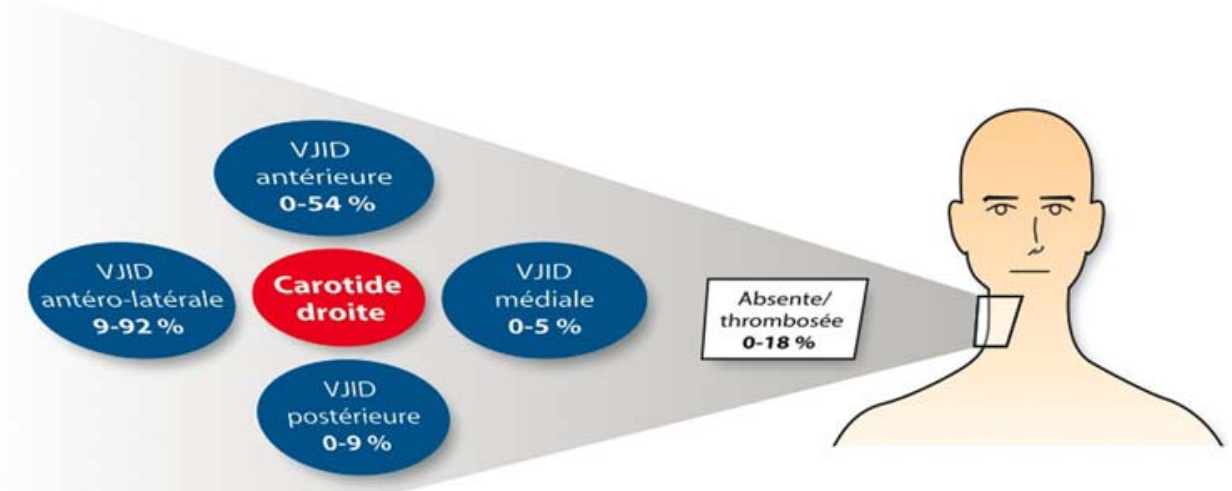


Tableau 1 Avantages et inconvénients de l'utilisation de l'échographie dans la pose de cathéters veineux centraux

VJI : veine jugulaire interne

\begin{tabular}{ll}
\hline Avantages & Inconvénients \\
\hline $\begin{array}{l}\text { 1- Visualisation des structures vasculaires } \\
\text { 2- Positionnement optimal de l'aiguille }\end{array}$ & $\begin{array}{l}\text { 1- Dépendance à la technologie } \\
\text { 2- Perte des habiletés pour la réalisation de } \\
\text { la technique à l'aveugle }\end{array}$ \\
$\begin{array}{l}\text { 3- Protection contre la ponction de la paroi } \\
\text { postérieure de la VJI }\end{array}$ & 3- Abstraction de son environnement \\
$\begin{array}{l}\text { 4- Placement précis du cathéter à l'intérieur de la VJI } \\
\text { 5- Permet la confirmation de la position }\end{array}$ & 4- Fausse sécurité \\
$\begin{array}{l}\text { du guide à l'intérieur de la VJI } \\
\text { 6- Rapidité d'exécution }\end{array}$ & 5- Coût du matériel plus élevé \\
7- Moins de tentatives & \\
8- Minimisation des complications & \\
\hline
\end{tabular}

Modeliar et coll., le diamètre de la jugulaire droite est significativement plus grand que celui de la gauche dans 65 $\%$ des cas. ${ }^{15}$ Dans une autre étude, Lichtenstein et coll. ont évalué l'asymétrie entre la veine jugulaire droite et gauche. Définie comme une aire deux fois plus grande par rapport au côté opposé, cette asymétrie a été notée dans $62 \%$ des cas, avec une jugulaire droite dominante chez $68 \%$ des patients. $^{13}$

Certains patients ont des repères anatomiques de surface difficiles ou même impossibles à trouver en raison d'une anatomie de surface altérée, d'un traitement de radiothérapie, de l'obésité, d'un œdème, d'une brûlure ou d'une chirurgie antérieure. Le succès de l'installation de cathéters veineux centraux dépend aussi de la grosseur de la veine jugulaire interne, de la volémie du patient, du positionnement, de la rotation de la tête, de la pression exercée sur la peau et de la présence de trauma. Pour toutes ces raisons et malgré une grande expérience de l'opérateur, il est parfois impossible de ponctionner la veine.

De plus, une ventilation à pression positive ajoutée à une rotation de la tête de $30^{\circ}$ du côté opposé à la ponction provoquent davantage la superposition des vaisseaux du cou. ${ }^{16,17}$ Enfin, l'utilisation du masque laryngé déplace le muscle sternocléidomastoïdien et rend plus difficile la palpation de la carotide commune.

\section{Techniques de canulation échoguidée}

Approche statique

Il existe deux approches possibles d'utilisation de l'échographie. La première consiste en une visualisation préalable des structures anatomiques uniquement pour fins de repérage anatomique. L'avantage de cette méthode dite « statique » demeure toutefois modeste mais appréciable par rapport à la technique à l'aveugle, car il est possible de visualiser la veine jugulaire interne et d'identifier des contre-indications à sa canulation. Il suffit ensuite de tracer sur la peau le trajet de la veine jugulaire interne au moyen d'un crayon stérile. Le reste de la technique se fait «à l'aveugle » en s'inspirant des repères visuels préalablement identifiés.

Approche dynamique

La seconde approche, dite «dynamique » ou de repérage échographique «en temps réel», est celle que nous préconisons. Elle inclut le repérage anatomique, mais permet aussi de suivre la progression de l'aiguille et de confirmer la position des guides vasculaires à l'intérieur de la veine jugulaire interne.

\section{Sélection de la sonde et de la modalité}

\section{Fréquence}

Deux types de sonde échographique sont disponibles sur le marché actuellement : les sondes à haute fréquence (ex. 8-12 MHz) et les sondes à basse fréquence (ex. 1-4 MHz). Le choix de la sonde repose sur la qualité de l'image à obtenir ainsi que sur la profondeur de la structure à atteindre. La résolution est cette capacité à discriminer deux structures anatomiques adjacentes. Plus la sonde émet dans les hautes fréquences, plus la longueur d'onde est courte, meilleure est la résolution. Par contre, la clarté de l'image obtenue par une haute fréquence se fait au détriment d'une visualisation superficielle (Figure 2). ${ }^{19}$ Habituellement, on utilise des sondes à haute fréquence parce que la veine jugulaire interne est relativement superficielle.

\section{Modes Doppler et 2D}

Avant le développement de l'échographie en deux dimensions (2D), le clinicien disposait uniquement d'un appareil avec mode Doppler, lequel permettait la 
Fig. 2 Images de la veine jugulaire interne droite (VJID) et de l'artère carotide droite (ACD) dans un plan transverse (A-C) et longitudinal (D-F). La sélection de la fréquence de la sonde d'échographie est basée sur l'importance relative de la résolution au détriment de la pénétration. Les images obtenues avec une sonde de 10 $\mathrm{MHz}$ (A, D) sont plus détaillées. Toutefois l'ACD, étant plus profonde, est mieux visualisée avec la sonde de $2 \mathrm{MHz}$ (Permission de Denault et coll.). ${ }^{18}$

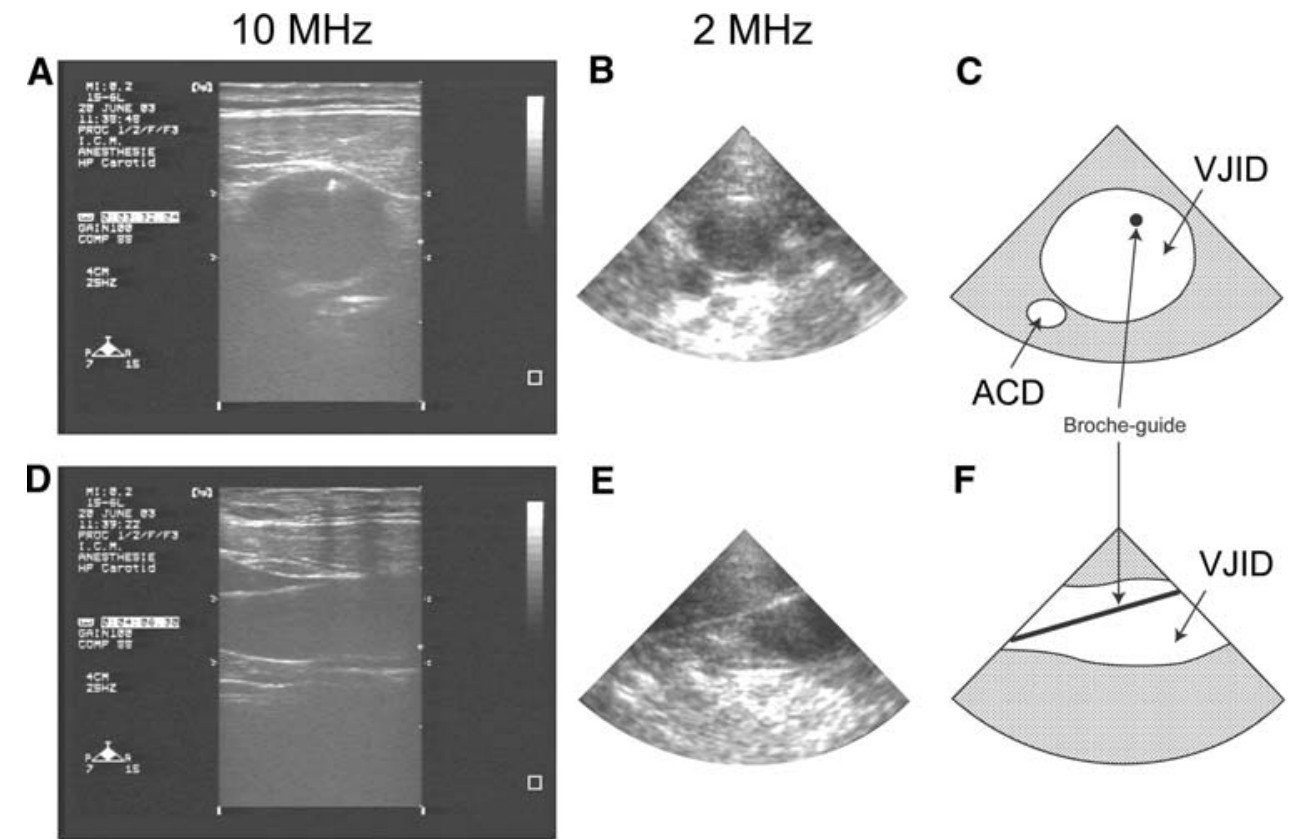

localisation des structures vasculaires via le signal sonore produit par le débit sanguin. Le signal veineux à basse fréquence et variant avec la respiration se différenciait alors du signal artériel pulsatile à haute fréquence. De nos jours on utilise l'échographie 2D afin de recréer l'image produite par les structures sous-cutanées. Il est possible de surajouter à ce mode 2D, le mode Doppler couleur, qui permet d'estimer la vélocité du sang et sa direction par rapport à la sonde d'échographie. Ce mode présente un avantage dans les cas de distorsion franche des structures anatomique et vasculaire.

\section{Technique de canulation}

Le matériel nécessaire à la réalisation d'une canulation sous échoguidage se compose d'une machine d'échographie, d'une sonde appropriée sélectionnée en fonction de la profondeur de la cible à ponctionner et d'une gaine ou enveloppe stérile afin d'isoler la sonde du patient. La présence d'un assistant facilite aussi la procédure. Le patient est tout d'abord placé en décubitus dorsal avec ou sans position de Trendelenburg et rotation légère de la tête vers le côté opposé. L'angle de rotation ne devrait jamais dépasser $30^{\circ}$ en raison de la distorsion anatomique générée. Une rotation cervicale exagérée peut entraîner une plus grande superposition de la veine jugulaire interne sur l'artère carotide et ainsi favoriser la ponction de cette dernière. ${ }^{20}$

La peau est désinfectée au niveau de tous les sites de canulation potentiellement utiles; il est recommandé de préparer les sites des veines jugulaire et sous-clavière (matériel supplémentaire Figure 7). La sonde d'échographie est par la suite déposée dans une gaine stérile et enduite de gelée stérile. Cette dernière servira à recouvrir l'extrémité de la sonde. La gelée sert d'interface et permet d'augmenter la transmission des ondes échographiques (matériel supplémentaire Figures 8-10). Comme interface entre la gaine et la peau, on utilise du sérum physiologique de préférence au gel sur la peau. S'il y perforation de la gaine, du gel s'écoulera et indiquera un bris d'étanchéité et par conséquent de stérilité. Par la suite, la sonde est déposée perpendiculairement à la peau de façon à obtenir une coupe transverse des vaisseaux (Figures 3 et 4). À ce stade le gain, la fréquence et la profondeur sont ajustés.

\section{Identification de la veine}

La veine possède deux caractéristiques propres : elle est compressible et son calibre varie selon le cycle respiratoire. En appliquant une pression au niveau hépatique, le reflux hépato-jugulaire généré aura tendance à dilater la veine jugulaire. La position de Trendelenburg augmente l'aire de la veine jugulaire de $37 \%$ en moyenne et le diamètre maximal peut être atteint avec un angle de $15^{\circ} .{ }^{19}$ Chez un patient non intubé, la manœuvre de Valsalva aura tendance à augmenter l'aire de la veine jugulaire interne de $25 \%{ }^{19}$ C'est à cette étape qu'il est important de reconnaître la thrombose ou l'atrophie de la veine jugulaire interne, étant des contre-indications absolues à la canulation jugulaire.

Axe de visualisation

$\mathrm{Au}$ cours de l'apprentissage de la technique, il est plus facile de commencer par une vue «court axe», 


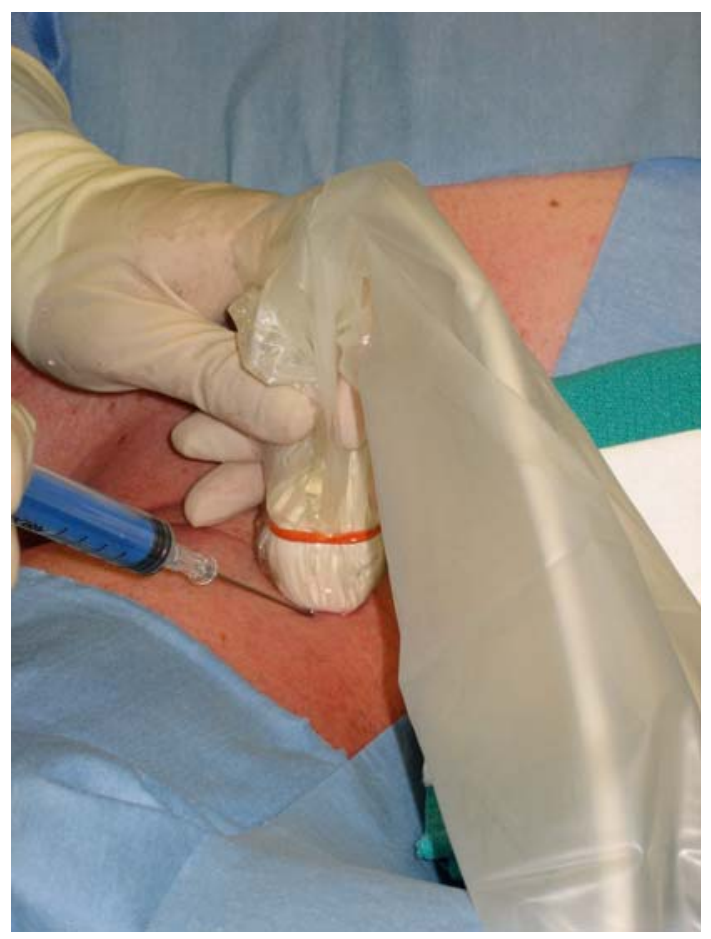

Fig. 3 Ponction de la veine jugulaire interne droite, vue de la tête du patient. Positionnement de la sonde pour une vue court axe en regard avec l'orientation de l'aiguille. L'aiguille est céphalade par rapport à la sonde

perpendiculaire à la veine, qui permet une meilleure présentation de la relation entre la veine jugulaire interne et l'artère carotide. Dans cette vue, on voit la veine et l'artère apparaissant rondes ou ovales (Figure 4). Alors qu'une main avance l'aiguille, l'autre avance la sonde ou la fléchit afin de maintenir la pointe de l'aiguille dans le plan de l'image. Avec l'expérience, l'opérateur préférera l'approche « long axe » parallèle à la veine, qui favorise une meilleure visualisation du trajet de l'aiguille dans son axe antéro-postérieur. De plus, elle entraîne une diminution du taux de ponction de la paroi postérieure de la veine jugulaire interne ainsi que la visualisation de la migration du guide à l'intérieur de la veine jugulaire interne (Figures 5 et 6). Dans cette vue, la veine est carrée et la carotide n'est habituellement pas visualisée. Afin de réussir cette technique, il est important de débuter par l'approche «court axe» et de s'assurer que l'aiguille se trouve exactement à midi par rapport à la veine. Une fois cette position obtenue, la sonde est tournée à $90^{\circ}$ pour obtenir une image «long axe ». La sonde est alors déplacée vers l'aiguille afin d'en couvrir une portion. Il convient alors de diminuer l'angle entre l'aiguille et la peau jusqu'à environ $30^{\circ}$. Une fois que la pointe de l'aiguille est visualisée avec la sonde d'ultrason, seule la main qui avance l'aiguille bouge et se mobilise pour être dans l'axe de l'image échographique. La technique longitudinale est celle utilisée

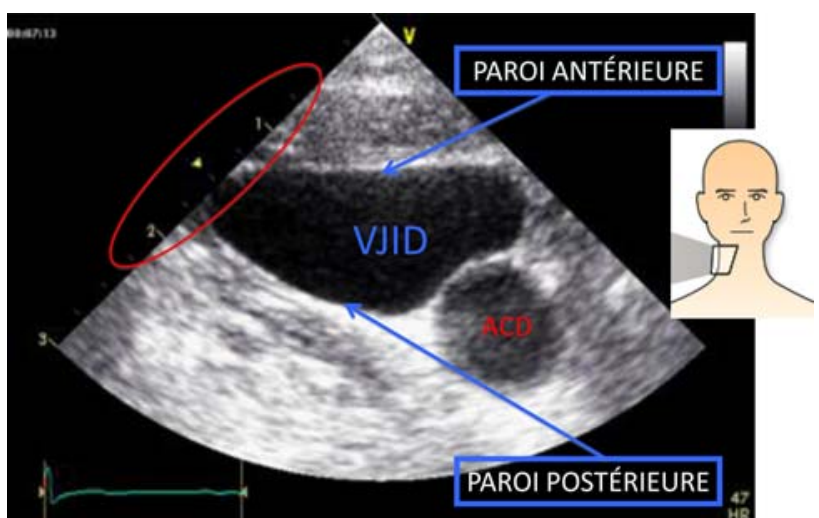

Fig. 4 Visualisation des structures cervicales droites. Notez la profondeur de la veine jugulaire interne qui se trouve à moins de 2 $\mathrm{cm}$ de la peau

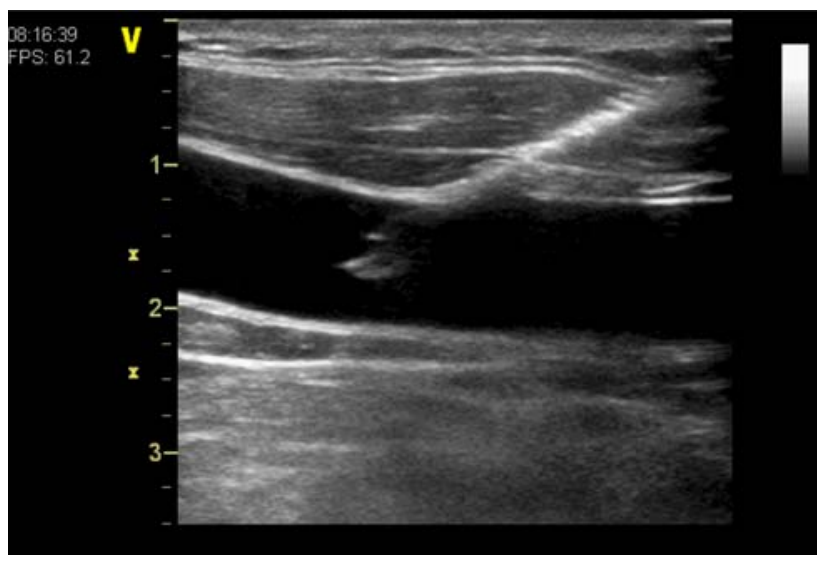

Fig. 5 Visualisation de la pointe de l'aiguille dans un plan longitudinal

et recommandée par les experts radiologistes. Quelle que soit la technique, il est impératif de ne jamais avancer l'aiguille sans la visualiser. Cette erreur, fréquente chez le débutant, explique pourquoi la technique de repérage échographique peut aussi être associée à des complications. La technique est résumée dans les vidéos 1 et 2 .

\section{Profondeur}

Les Figures 5 et 6 montrent que la veine est relativement superficielle par rapport au plan cutané et se situe à environ $1,5-2 \mathrm{~cm}$ de profondeur. Il est donc inutile et même risqué d'avancer l'aiguille au-delà de $2,5-3 \mathrm{~cm}$. De plus, en pénétrant plus profondément, il y a un risque de ponctionner la partie postérieure de la veine et ainsi entraîner un hématome. La technique longitudinale permet d'éviter ce piège.

Il est important durant la ponction sous échographie de bien suivre le trajet de la pointe de l'aiguille et non la dépression tissulaire occasionnée par celle-ci. De plus, 


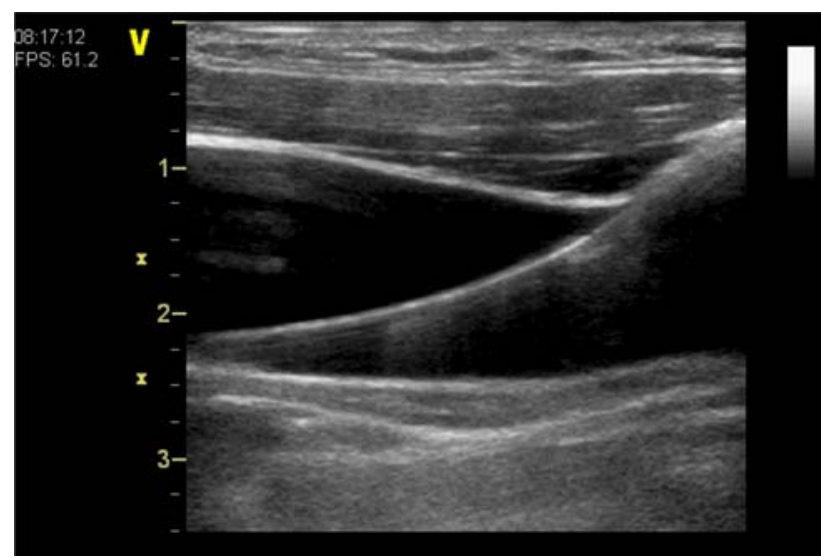

Fig. 6 Visualisation du guide dans la veine jugulaire interne droite dans un plan longitudinal

avant de perforer la peau, il est primordial de visualiser le plan cutané où la ponction est prévue afin de respecter les structures. Ainsi, on évitera une ponction trop latérale, dans le muscle sternocléïdomastoïdien, ou trop inféro-médiale, dans la glande thyroïde ou l'artère carotide. Une fois la veine localisée et ponctionnée, la sonde peut être mise de côté et le guide inséré. L'aiguille est ensuite retirée. Ensuite, la position du guide dans la veine jugulaire interne est confirmée avec la sonde d'échographie. Une variation plus dynamique de cette technique consiste à modifier l'axe de visualisation afin d'apprécier la migration en temps réel du guide en vue longitudinale. $\mathrm{Si}$ une sonde d'échographie transoesophagienne a été préalablement installée, l'observation du guide à l'intérieur de l'oreillette droite confirmera hors de tout doute une canulation veineuse appropriée.

\section{Évaluation de la technique}

\section{Avantages}

Plusieurs études démontrent des bénéfices clairs à l'utilisation de l'échographie, ${ }^{1,5,7}$ dont une diminution du taux d'échec de la technique, un nombre moindre de ponctions, une réduction des complications et un temps d'exécution plus rapide. ${ }^{21-24}$ On obtient ces résultats grâce à la clarification du trajet et de la position relative de l'aiguille en regard des structures. L'échographie 2D permet aussi de prédire les variations anatomiques et de confirmer la perméabilité de la veine jugulaire interne. L'étude la plus importante comparant le repérage échographique à la technique « à l'aveugle » a été réalisée aux soins intensifs chez 900 patients par Karakitsos et coll. ${ }^{25}$ Les opérateurs avaient dix ans d'expérience dans l'insertion d'accès vasculaires sans échographie et cinq ans d'expérience en repérage échographique. Le taux de réussite était de $100 \%$ avec l'échographie et de $94 \%$ selon les repères traditionnels. Le temps d'accès était de 17 secondes avec l'échographie, comparativement à 44 secondes avec la technique à l'aveugle, avec un nombre moyen d'essais moindre ( 1,1 et 2,6 , respectivement). L'échographie était associée à un taux de complications réduit de $57 \%$. Les auteurs de l'étude ont observé une différence significative en faveur de l'échographie quant à l'incidence de ponction de l'artère carotide $(1,1 \%$ vs 10,6 $\%)$, d'hématome $(0,4 \%$ vs $8,4 \%)$, de pneumothorax (0\% vs $2,4 \%)$, d'hémothorax (0 \% vs $1,7 \%$ ) et d'infections $(10,4 \%$ vs $16 \%) .{ }^{25}$ Hind et coll. et Calvert et coll. rapportent eux aussi une diminution de $86 \%$ des échecs ainsi qu'une baisse de $41 \%$ d'échec au premier essai. ${ }^{7,26}$ C'est d'ailleurs ces études qui servent de base aux recommandations du National Institute for Clinical Excellence. Dans une étude relative aux poursuites, Domino et coll. ont conclu que sur un collectif de 110 patients inclus dans un processus légal, l'utilisation de l'échographie aurait pu prévenir la survenue d'incidents chez 28 d'entre eux. ${ }^{27}$

\section{Pneumothorax}

L'insertion de cathéters veineux centraux est, dans la majorité des cas, réalisée en début d'intervention chirurgicale tandis qu'une radiographie pulmonaire ne peut être effectuée qu'à la toute fin de l'intervention. La technique du «glissement pleural» consiste en une évaluation rapide du poumon et de la plèvre à l'aide de l'échographie et elle a été démontrée efficace pour détecter la présence de pneumothorax. En effet, sa valeur prédictive négative frôlait le $100 \%$ dans les études. ${ }^{28-30}$ Ainsi, si le signe du «glissement pleural» n'est pas présent, le pneumothorax est confirmé dans l'immédiat et nous évite tout délai diagnostique. De plus, cette technique récente mais éprouvée cliniquement a été démontrée comme étant plus efficace pour détecter les pneumothorax de petite taille que la radiographie pulmonaire (vidéo 3 ). ${ }^{31}$

\section{Inconvénients}

Comme toute nouvelle technique, l'échographie demande une formation générale sur les principes de base. Ces notions s'acquièrent relativement rapidement et se traduisent par une courbe d'apprentissage rapide. Toutefois, l'utilisation systématique de l'échographie peut provoquer une dépendance technologique, avec une crainte légitime de perdre ses habilités techniques faute de pratique. En cas d'indisponibilité de l'appareil ou en situation d'urgence, le clinicien peut devenir inconfortable et ne plus être en mesure de procéder. Cette dépendance technique se compare à l'utilisation du laryngoscope dans 
l'intubation. Cet outil essentiel à notre pratique est disponible dans toute situation urgente et élective. Il est possible que l'échographie aura la même évolution et fera partie du matériel de base d'anesthésie. Il existe aussi un coût réel d'acquisition auquel on ne peut se soustraire. L'échographie 2D peut aussi susciter un sentiment de fausse sécurité et ainsi provoquer l'oubli de gestes et de mouvements habituels qui assurent la sécurité. En se concentrant exclusivement sur l'image échographique obtenue, on peut aussi omettre de regarder le patient et son environnement. Le tableau résume les avantages et inconvénients de l'utilisation de l'échographie dans la pose des cathéters veineux centraux.

\section{Coûts}

L'analyse comparative des coûts doit prendre en compte les traitements des complications associées à l'installation des cathéters centraux et l'hospitalisation prolongée qu'ils nécessitent. Ainsi, les coûts liés à une non-utilisation de l'échographie sont non négligeables. Des modèles économiques élaborés en Angleterre par le Health Technology Assessment Programme ont démontré que l'utilisation de l'échographie pouvait entraîner une économie de près de $4000 \$$ par tranche de 1000 procédures. Ces calculs tenaient compte du coût lié aux ponctions artérielles, aux pneumothorax et à l'acquisition du matériel. ${ }^{26}$ Dans une autre étude évaluant l'échographie pour les ponctions sous-clavières, les chercheurs se sont intéressés au nombre de trousses utilisées. Les utilisateurs qui se servaient de repères cutanés utilisaient souvent plus d'une trousse pour réaliser leur ponction comparativement à seulement une pour les échographistes. ${ }^{31}$ Ainsi, malgré le coût d'acquisition plus élevé de la technologie échographique, il est possible de justifier ces dépenses par le nombre réduit de complications qu'elle entraîne.

\section{Perception actuelle des anesthésiologistes}

Malgré ces données probantes, les cliniciens sont souvent réticents à utiliser l'échographie pour l'installation de cathéters veineux centraux. En effet, selon un sondage réalisé auprès des membres de la Société américaine des anesthésistes cardiaques (Society of Cardiovascular Anesthesiologists), les deux tiers des répondants affirment n'avoir jamais ou que rarement utilisé l'échographie. Aussi, seulement $15 \%$ des membres l'emploient de façon systématique. Dans environ $45 \%$ des cas, ces anesthésiologistes mentionnent ne voir aucune nécessité à l'utiliser et ce, en dépit du fait que plus de $75 \%$ d'entre eux ont été témoins de complications. Le coût, la non-disponibilité du matériel et les délais engendrés sont parmi les autres raisons exprimées par les cliniciens pour justifier la sous-utilisation de l'échographie. De façon surprenante, on constate dans cette étude que plus de $45 \%$ des anesthésiologistes utilisent encore la couleur et la non-pulsatilité du retour sanguin pour confirmer le positionnement de l'aiguille, tout en sachant que cette technique peut s'avérer faillible. ${ }^{4}$ À la lumière de ces données, il est évident que bien des efforts sont encore nécessaires afin de promouvoir l'utilisation de l'échographie pour l'installation de cathéters centraux auprès des médecins.

\section{Conclusion}

L'utilisation de l'échographie pour la pose d'accès vasculaire diminue les complications mécaniques et infectieuses, augmente le taux de succès et l'efficacité tout en diminuant possiblement les coûts et l'inconfort des patients. Dans la mesure où le matériel est disponible et la formation adéquate, il est recommandé d'utiliser l'échographie chez tous les patients nécessitant un accès veineux central. Cette technique devrait être privilégiée aussi bien par les novices que par les cliniciens d'expérience et ce, en première intention, spécialement lorsqu'il y a obésité, œdème, troubles de coagulation, repères anatomiques introuvables ou ventilation à pression positive aux soins intensifs. Sans être normatif, il sera de plus en plus difficile de justifier la non-utilisation de l'échographie dans l'installation des cathéters centraux en raison des bénéfices avérés qui contribuent ultimement à l'amélioration de la sécurité chez nos patients.

\section{Cas clinique}

Un homme de 66 ans obèse se présente à l'urgence en œdème pulmonaire aigu secondaire à un choc cardiogénique. Ce patient a des antécédents d'hypertension artérielle traitée, de dyslipidémie traitée, de diabète de type II insulino-dépendant, de maladie coronarienne athérosclérotique ayant nécessité l'installation de tuteurs ainsi qu'une insuffisance rénale terminale hémodialysée sur une base régulière. Le patient est en position semi-assise, il est essoufflé et présente beaucoup de tirage. De plus, sa pression artérielle est basse à $85 / 40 \mathrm{mmHg}$. Votre collègue urgentologue désire installer un cathéter veineux central pour administrer des agents vasopresseurs et demande votre aide, pensant que la procédure sera plus difficile qu'à l'accoutumée.

\section{Directives pour compléter le module DPC}

1. Lisez les références en gras.

2. Rendez-vous à : https://www.cpass2.umontreal.ca/self assessmentprogram/ ; et choisissez le module actuel 
(L'échographie dans la canulation de la veine jugulaire interne).

3. Répondez aux questions à choix de réponses concernant le cas clinique.

4. Après avoir saisi toutes vos réponses, vous aurez accès aux explications d'experts pour tous les choix possibles.

5. Les participants peuvent réclamer un maximum de quatre heures de DPC pour un total de huit crédits sous la Section 3 du programme de DPC du Collège royal des médecins et chirurgiens du Canada.

Funding None.

Conflict of interest None declared.

\section{References}

1. Maecken T, Grau T. Ultrasound imaging in vascular access. Crit Care Med 2007; 35(5 Suppl): S178-85.

2. English IC, Frew RM, Pigott JF, Zaki M. Percutaneous catheterisation of the internal jugular vein. Anaesthesia 1969; 24: 521-31.

3. Muralidhar $K$. Left internal versus right internal jugular vein access to central venous circulation using the Seldinger technique. J Cardithorac Vasc Anesth 1995; 9: 115-6.

4. Bailey PL, Glance LG, Eaton MP, Parshall B, McIntosh S. A survey of the use of ultrasound during central venous catheterization. Anesth Analg 2007; 104: 491-7.

5. McGee DC, Gould MK. Preventing complications of central venous catheterization. N Engl J Med 2003; 348: 1123-33.

6. Feller-Kopman D. Ultrasound-guided internal jugular access: a proposed standardized approach and implications for training and practice. Chest 2007; 132: 302-9.

7. Hind D, Calvert N, McWilliams $R$, et al. Ultrasonic locating devices for central venous canulation: meta-analysis. BMJ 2003; 327: 361.

8. Ullman JI, Stoelting RK. Internal jugular vein location with the ultrasound Doppler blood flow detector. Anesth Analg 1978; 57: 118.

9. Legler D, Nugent $M$. Doppler localization of the internal jugular vein facilitates central venous canulation. Anesthesiology 1984; 60: 481-2.

10. Rothschild JM. Ultrasound guidance of central vein catheterization. Making health care safer: A critical analysis of patient safety practices. Agency for Healthcare Research and Quality. URL available from: http://www.ahrq.gov/clinic/ptsafety/chap21.htm (accessed January 2010)

11. American College of Emergency Physicians. Use of ultrasound imaging by emergency physicians. Ann Emerg Med 2001; 38: 469-70.

12. Grebenik CR, Boyce A, Sinclair ME, Evans RD, Mason DG, Martin $B$. NICE guidelines for central venous catheterization in children. Is the evidence base sufficient? Br J Anaesth 2004; 92: 827-30.
13. Lichtenstein D, Saifi $R$, Augarde $R$, et al. The internal jugular veins are asymmetric. Usefulness of ultrasound before catherization. Intensive Care Med 2001; 27: 301-5.

14. Armstrong PJ, Sutherland R, Scott DH. The effect of position and different manoeuvres on internal jugular vein diameter size. Acta Anaesthesiol Scand 1994; 38: 229-31.

15. Samy Modeliar S, Sevestre MA, de Cagny B, Slama M. Ultrasound evaluation of central veins in the intensive care unit: effect of dynamic manoeuvres. Intensive Care Med 2008; 34: 333-8.

16. Riley RH, Gaylard DG, Wright DA, Davies PC. The LMA and difficulty with internal jugular vein canulation. Anaesthesia 1999; 54: 1224

17. Takeyama K, Kobayashi H, Suzuki T. Optimal puncture site of the right internal jugular vein after laryngeal mask airway placement. Anesthesiology 2005; 103: 1136-41.

18. Denault AY, Couture P, Buithieu J, Tardif JC. Transesophageal Echocardiography Multimedia Manual: A Perioperative Transdisciplinary Approach. Marcel Dekker; 2005.

19. Mallory DL, Shawker T, Evans RG, et al. Effects of clinical maneuvers on sonographically determined internal jugular vein size during venous cannulation. Crit Care Med 1990; 18: 1269-73.

20. Sulek CA, Gravenstein N, Blackshear RH, Weiss L. Head rotation during internal jugular vein canulation and the risk of carotid artery puncture. Anesth Analg 1996; 82: 125-8.

21. Abboud PA, Kendall JL. Ultrasound guidance for vascular access. Emerg Med Clin North Am 2004; 22: 749-73.

22. Denys BG, Uretsky BF, Reddy PS. Ultrasound-assisted canulation of the internal jugular vein. A prospective comparison to the external landmark-guided technique. Circulation 1993; 87: 1557-62.

23. Verghese ST, McGill WA, Patel RI, Sell JE, Midgley FM, Ruttimann UE. Ultrasound-guided internal jugular venous cannulation in infants: a prospective comparison with the traditional palpation method. Anesthesiology 1999; 91: 71-7.

24. Hunter M. Peripherally inserted central catheter placement @ the speed of sound. Nutr Clin Pract 2007; 22: 406-11.

25. Karakitsos D, Labropoulos $N$, de Groot E, et al. Real-time ultrasound-guided catheterisation of the internal jugular vein: a prospective comparison with the landmark technique in critical care patients. Crit Care 2006; 10: R162.

26. Calvert N, Hind D, McWilliams RG, Thomas SM, Beverley C, Davidson $A$. The effectiveness and cost-effectiveness of ultrasound locating devices for central venous access: a systematic review and economic evaluation. Health Technol Assess 2003; 7: 1-84.

27. Domino KB, Bowdel TA, Posner KL, Spitellie PH, Lee LA, Cheney $F W$. Injuries and liability related to central vascular catheters: a closed claims analysis. Anesthesiology 2004; 100: 1411-8.

28. Blaivas $M$, Lyon $M$, Duggal $S$. A prospective comparaison of supine chest radiography and bedside ultrasound for the diagnosis of traumatic pneumothorax. Acad Emerg Med 2005; 12: 844-9.

29. Lichtenstein DA, Мепи $Y$. A bedside ultrasound sign ruling out pneumothorax in the critically ill. Lung sliding. Chest 1995; 108: $1345-8$.

30. Lichtenstein DA, Meziere G, Lascols $N$, et al. Ultrasound diagnosis of occult pneumothorax. Critical Care Med 2005; 33: 1231-8.

31. Gualtieri E, Deppe SA, Slipperly ME, Thompson DR. Subclavian venous catheterization: greater success rate for less experienced operators using ultrasound guidance. Crit Care Med 1995; 23: 692-7. 